臭気判定士の仕事

\title{
下水処理における臭気業務について
}

\author{
石塚 健一
}

\section{1. 臭気判定士の取得動機}

私は，以前，環境分析会社に勤務していました，その 中で, 悪臭苦情に関する調查や脱臭設備の除去性能確認 調查, 焼却施設の排出口 (2 号基準) の調査など悪臭防 止法に関する測定業務を行ってきました。このような業 務に対し, 书客様にきちんとした説明や原因の把握, 対 策等を行える様になりたいと思い, 臭気判定士を取得し ました．また，大学の大先輩から強い勧めがあったこと も取得理由の一つにあります。

\section{2. 今までの業務について}

環境分析会社に勤務中は，悪臭防止法に関する調査・ 報告書作成業務を主に担当しました，印象に残っている 業務として, ある自治体が悪臭物質の濃度規制から臭気 指数規制導入を検討しており, そ こからの委託で様々な業種の臭気 を測定し，その結果を基に臭気指 数規制が無事導入されたことは, 私にとって良い経験になりました。

\section{3. 今現在の仕事内容について}

私は, 現在, 東京都下水道サ一 ビス株式会社に勤務しています。 当社は東京都下水道局の業務を補 完代行し，下水道事業を支える パートナーとして下水道サービス

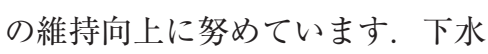

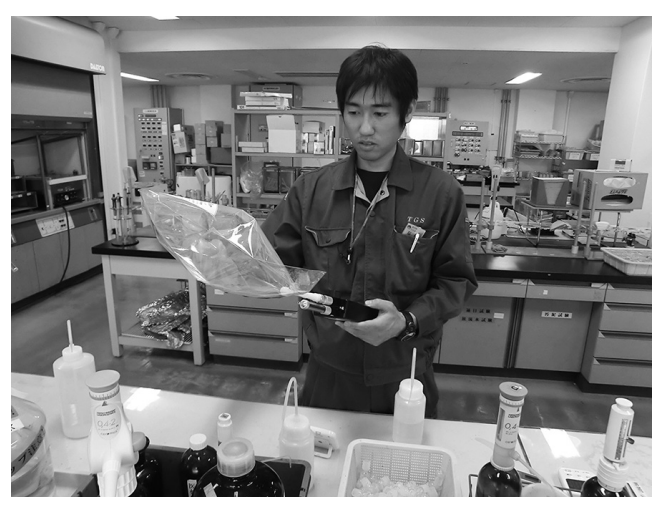

試験室にて
こり易く, 硫化水素等の悪臭物質が発生しやすい状況で す。また，污泥を焼却した際に発生する排気ガスや放流 水など悪臭防止法の $1 \sim 3$ 号基準全てに該当し, 臭気は 下水处理に扔いて重要な管理項目の一つです．特に硫化 水素は, 夏季に高濃度になり易く, 中毒で死亡する危険 性もあることから，作業環境の面に扔いても非常に重要 な管理項目です。

下水道局に寄せられる臭気苦情のほとんどはビルピッ トからの硫化水素によるものですが, 下水処理施設の近 隣では住宅の増加や商業化に伴い, より一層の臭気対策 が求められています。このため, 主要な発生源には覆蓋 や密閉化等の対策が行われています。しかし，これらの 対策は臭気物質自体を削減しているわけではなく, 生物 脱臭・活性炭脱臭等の脱臭設備や薬品添加による対策が 必要不可欠となります, 実際に, 高濃度臭気の発生要因 は, 脱臭設備の活性炭の経年劣化 が多くの割合を占めています。こ のため, 主要な発生源では日頃か ら硫化水素の測定を行い, 必要に 応じて薬品の添加率を変更しなが ら発生を抑制するなど, 臭気の管 理に気を配っています。

ポンプ所, 水再生センターでは 担当者が現場に行き, 臭気が漏れ 出していないかの確認も行ってい ます，また，年に数回，外部委託 による臭気測定を行い，活性炭の 吸着能力が低下していないか確認 道の入口であるお客様対応や下水管路の維持管理に始ま り, 下水処理の出口部分にあたる水処理・污泥処理施設 の保全管理や運転管理の業務まで総合的に行い, 東京都 （23区）の生活基盤を支えています.

その中で, 私の所属する課は, 水処理・污泥処理施設 で試料を採取・分析し, 各処理工程が適切に機能してい るか検査する業務を行っています，特に，水処理施設で は, 流入変動の大きい下水に対し, 微生物をうまくコン トロールしながら, 放流水質基準を遵守できるようサ ポートしています，現在，私の所属する課は臭気に関す る業務に関わっていませんが，施設管理部では保全管理 業務の中で，臭気に関する業務を行っています，下水処 理では, 各家庭や工場等から発生した污水が下水管を経 て, 水処理施設に運ばれます。 その際, 下水の腐敗が起 するとともに，悪臭防止法の基準を順守できるように維 持管理しています.

\section{4. 今後臭気判定士に求められること}

臭気は物質同士の相乗・相殺効果や人により，におい に対する個人差があるなど, 問題解決が難しい場合もあ り, 奥深い分野です，臭気判定士に限らず，業務の目的 をきちんと把握し，目的に沿った調查・分析を行うこと が大切であると思います，日々の業務の中で，ついつい 自分達の立場や㧍客様優先になってしまうと本来の目的 を見失ってしまう可能性もあります。そそのため，扔客様 等とコミュニケーションを図り, 目的をきちんと把握し た上で, 自身の持っている知識・経験を活用し, 様々な 課題を克服していくことが求められると思います.

石塚 健一 (いしづか けんいち)

東京都下水道サービス株式会社施設管理部水質管理課 